\title{
RIGHTS, DUTIES AND REMEDIES OF THE PARTIES TO A SALE OF PERSONAL PROPERTY WHICH IS TO BE DELIVERED AND PAID FOR IN IN- STALMENTS.
}

It will be convenient first to consider the legal relations of the immediate parties to the sale, and then to inquire what claims third parties have to goods sold in this manner, against the vendor and vendee. Sales on what is now known as the "instalment plan" are of comparatively recent origin, though contracts for successive deliveries will be found in the old reports. In neither case, however, have the courts taken a broad view of the subject with regard to the future development of the law, and each case seems to have been decided according to the equity of the facts in issue, thus causing a confusion in the cases which will be found upon inquiry to be more apparent than real. It is probable that, in the absence of express stipulation at least, the failure of the vendee to pay an instalment does not so readily work a forfeiture of the contract as the failure of the vendor to deliver. This is partly because the legal rate of interest is supposed to be sufficient compensation for the non-payment of money, and partly because recovery can more easily be had in an action. The question of the vendor's right to rescind for failure to pay an instalment depends, however, upon whether or not the contract is entire. 1 Prima facie, such contracts are severable, ${ }^{2}$ but merely because a contract consists of several entire items which are not to be performed at the same time, and each of which has a stipulated value, will not be a reason for refusing to construe it as entire. ${ }^{8}$ If each stipulation "so went to the root of the matter as to make its performance a condition of the obligation to proceed in the contract" it is an entire contract. 4 In all cases intention governs, ${ }^{5}$ and the mode of measuring the price will not render the contract severable if it was intended to be

1 Thomson $v$. Conover, 3 Vroom 466.

2 Quigley $v$. DeHaas, I Norris 267.

3 Smith $v$. Lewis, 40 Ind. 98.

4 Catlin $\nu$. Tobias, 26 N. Y. 217 ; Jenness v. Shaw, 35 Mich. 20.

5 Tipton $v$. Feitner, 20 N. X. 423. 
entire. ${ }^{8}$ If, however, there is an express or implied apportionment of the consideration the contract is severable, ${ }^{7}$ and where it is provided that payment shall be made upon the delivery of each instalment it will be so construed. 8 If, therefore, the contract be construed as entire, and a fortior $i$ if the parties to the contract express their intention that the contract shall be entire, or say that the non-payment of any one instalment shall work a forfeiture as long at least as the contract remains executory the forfeiture will be enforced. 9 This is the usual manner of drawing up contracts of sale on the instalment plan, and as freedom of contract is encouraged by the courts, they will usually be carried out according to their intendment. If it is part of the contract that upon failure to pay an instalment the vendor may recover back his property, it has been said that the fact that he does so does not constitute a rescission of the contract, but a fulfillment of it according to its terms. ${ }^{10}$ The vendor would not be guilty of trespass in so doing, ${ }^{11}$ even if he use deception in retaking his property; ${ }^{12}$ but in some jurisdictions it is said that before the retaking he must exercise his right to rescind. ${ }^{13}$ In any case the vendor need not tender back the partial payments already made. ${ }^{14}$ But if the goods delivered were not such as were stipulated for the vendor would be obliged to pay back such instalments as he has received, ${ }^{15}$ together with damages in case there was a warranty, the contract being then at an end. ${ }^{16}$ It has been said that if the article is not merchantable the vendee may show this fact and that as much as the article is worth has been paid, and thus keep the goods and be absolved from further payments. ${ }^{17}$ It is submitted that this is not good law. Each failure to pay an instalment. is a fresh - breach of the contract. ${ }^{18}$ The strict carrying out of such contracts, however, oftentimes leads to harsh results, as in the case of Whelan $v$. Couch, ${ }^{19}$ where the

6 Shinn $v$. Bodine, 60 Pa. 182.

7 Lucesco Oil Co.v. Brewer, 66 Pa. 35I; Rugg \& Bryan v. Moore, Iro Pa. 236.

8 Sawyer v. Chicago \& N. W. R. R. Co., 22 Wis. 385 .

9 Tyson $v$. Doe, I5 Vt. 57 .

10 Latham $v$. Sumner, 89 Ill. 233.

11 Smith $v$. Sozo, 42 Mich. 6.

12 North $v$. Williams, I2 Centr. Rep. (Pa.) 369.

13 Giddey $v$. Altman, 27 Mich. 206.

14 Haviland $v$. Johnson, 7 Daly 297; Duke $v$. Snackleford, 56 Miss. 552.

15 Singer Sewing Mach. Co. v. Treadway, 4 Brawd. (IIl.) 57.

16 Dike v. Reitlinger, 23 Hun. 24I ; American \&c. Co. v. Gillette, 88 Mich. 23I.

17 Guilford, Woods \& Co. v. McKinley, 6I Ga. 230.

18 Hunter-ข.-Daniel, 4 Hare 432.

1926 Grant's Ch. Rep. 74. 
tender of the last instalment of $\$ 9$ on the sum of $\$ 1,078$ upon Monday was refused because it had been due on the previous Saturday, and it was held to work a forfeiture. The sum thus forfeited was not an extortionate sum regarded as rent, but whether this be so or not in a given case such a result must always come from the logical working out of the contract. Upon default the seller may resume possession, ${ }^{20}$ even though nothing is said in the contract on this subject, this being an implied condition of the sale. ${ }^{21}$ When possession is resumed this in itself puts an end to the contract and the seller cannot recover any balance due on the purchase price. ${ }^{22}$ But, if he prefer, the vendor may bring an action on the price, ${ }^{23}$ in which case the buyer cannot offer to rescind. ${ }^{24}$ The accidental destruction of the property will probably not excuse the vendee from paying the purchase price.25 There may be an express or implied waiver of the failure to pay an instalment when due, such as the receipt of a subsequent instalment. ${ }^{26}$ But a waiver of one forfeiture is not relevant evidence of a waiver of subsequent forfeitures. ${ }^{27}$ Such a waiver will give the buyer a right to complete his title on payment of the residue, but an agent to collect has no power to make such a waiver. ${ }^{28}$ If no time is mentioned for payment it will be presumed that it is to be made on delivery, ${ }^{29}$ but if the payments are not to be made in instalments the time of payment will be on delivery of all the goods, although the deliveries are successive. ${ }^{30}$ The vendee must prove he was ready to receive and pay for the goods as delivered. ${ }^{31}$ The purchaser may at any time tender the balance, notwithstanding the instalments are not yet due, and thus perfect his title. ${ }^{22}$ If the vendee fail to pay an instalment the vendor may refuse to make a subsequent delivery until this is paid, although

20 Wiggins $v$. Snow, 89 Mich. 476; Goldie $v$. Rascony, 4 Hont. L. Rep. 313; Siere $v$. McGovern, $65 \mathrm{Cal}, 244$.

21 Edwards $v$. Symonds, 65 Mich. 348.

22 Hineman $v$. Matthews, $138 \mathrm{~Pa} .204$.

23 Monroe $v$. Williams, 37 S. C. 8 r.

24 Appleton $v$. Norwalk, 53 Conn. 4.

25 Burnley $v$. Tufts, 66 Miss. 48.

28 Hutchings $v$. Munger, 4I N. Y. I55; Cushman $v$. Jewell, 7 Hun. 525-

Contra: Hegler v. Eddy, 43 Cal. 597.

27 Hill $v$. Townsend, 69 Ala. 286.

28 Hutchings $\nu$. Munger, supra.

29 Metz v. Albrecht, 52 Ill. 49 I.

30 Timmons $v$. Nelson, 66 Barb 594 .

31 Bronson $v$. Wiman, 4 Seld. I82; Mount $v$. Lyon, 49 N. Y. 552.

32 Cushman $v$. Jewell, supra. 
otherwise this would be a breach of the contract upon his part. 83 Although these contracts come under the head of conditional sales, it has been held that an action will lie for an absolute promise to pay on the part of the vendee. ${ }^{34}$ If he has been sued for the price of any one delivery, it seems that he must set up his damages for failure to make subsequent deliveries by way of counter-claim, otherwise such defense. is waived. ${ }^{35}$ The purchaser cannot accept an instalment delivered too late and refuse to pay for it on the ground that he sets the payment off against the damages sustained by non-delivery. ${ }^{36}$ If the sale takes the form of a lease it is nevertheless generally construed as a conditional sale, ${ }^{87}$ and parol evidence is admissible to show that the parties so understood it. ${ }^{38}$ The vendor cannot treat such a contract as a lease and sue for damages for its breach. ${ }^{39}$ Some courts have refused to allow such contracts to work a forfeiture of the instalment already paid unless it is clear that the measure of damages thus stipulated for is based on adequate compensation. ${ }^{40}$ It has accordingly been held that when the vendor resumes possession the buyer can recover an equitable proportion of the sums already paid. ${ }^{41}$ This proportion would be the instalments paid less a reasonable sum for hire and damages. ${ }^{22}$ This seems to the writer to be an unwarrantable interference with the freedom of contract. In some States the matter has been regulated by statute, as in Missouri ${ }^{43}$ and Ohio, ${ }^{44}$ where it is provided that the vendor cannot retake his property without tendering back a reasonable amount. Such a statute is not void as taking away property without due process of $1 \mathrm{aw},{ }^{45}$ but it is at the best meddlesome legislation. Equity, however, will not aid the vendor to recover back his property unless he make restitution ${ }^{46}$ and lapse of time will readily be construed into a waiver. ${ }^{47}$

33 Raabe $v$. Squier, 148 N. Y. 8I.

34 Marvin Safe Co. v. Emanuel, 2r Abb. N. C. $18 \mathrm{I}$; Affirmed I4 S. R. 68I. 35 O'Neill $v$. Crotty, 16 Daly, 474.

38 Bradley $v$. King, 44 III. 339.

37 Greer v. Churoh, I3 Bush. 430.

38 Wire Book Sewing Mach. Co. v. Crowell, 8 Atl. Rep. 22.

39 Loomis v. Bragg, 50 Conn. 228.

40 Johnston $v$. Whittemore, 27 Mich. 463.

41 Simon ข. Edmundson, 1o Pa. Co. Ct. Rep. 315; Preston v. Whitney, 23 Mich. 260.

22 Snook v. Raglan, 15 S. E. Rep. $364(\mathrm{Ga}$ ).

43 Rev. St. of Mo., Sec. 2508.

44 Ohio, Act of 1885, p. 239, Sec. 2.

45 Weil $v$. State, 46 Ohio St. 450.

46 Lincoln v. Quynn, 68 Ma. 299.

47 Gorham v. Holden, 79 Me. 317. 
The later English cases, and some American cases, have formulated a rule which, if not carried too far, should be useful in solving these contracts. The doctrine ought not to be applied to contracts in which there is an express stipulation that upon one default in payment the vendor may resume possession and the amount paid shall be regarded as rent. These agreements solve themselves, with the modifications and exceptions noted above. But where nothing is said on this subject, and there is a default, it has been decided that this in itself will not work a forfeiture unless from the fact of the default it may be reasonably surmised that the vendee did not intend to carry out the contract. Thus in the leading case of Freeth $v$. Burr. 48 a failure to pay an installment because of a mistaken impression on the part of the buyer that he could withhold payment as a set-off for the failure to deliver an earlier instalment, was held not to entitle the vendor to rescind. This case is said to have been decided on the authority of Withers $v$. Reynolds, ${ }^{40}$ though the analogy is not apparent. And in a later case this doctrine was approved, the reason for the failure to pay being the erroneous advice of counsel, and it was said: "You must look at the circumstances of each case. * * * You must examine what the conduct is, so as to see whether it amounts to a renunciation." 50 An intention to abandon might be inferred from the fact that the vendee refused to give notes as agreed upon the delivery of each instalment, and the vendor would be entitled to rescind before the completion of the contract, 51 or from the failure to sell the articles for cash and remit payments promptly if this were part of the contract. ${ }^{52}$ But if the vendor choose to treat the contract as subsisting he may sue for each instalment as it falls due. ${ }^{53}$

In this country several cases are at least authority for the proposition that "where the failure to pay is due to some accident or oversight, or is attended with facts and circumstances which are inconsistent with an intention to abandon the contract, the buyer will not forfeit the benefits of the sale if he makes a tender of the future instalments of payments," 54 thus putting

48 L. R., 9 C. P. 208.

492 B. \& A. 882 .

50 Mersey Steel \& Iron Co. v. Naylor, L. R., 9 Ap. Cases 434.

51 Nichols $v$. Scranton Steel Co., I37 N. Y. 47r; Pattridge v. Gildermeister, I Keys 93; Stockdale $v$. Schuyler, 8 N. Y. Sup. 813 .

52 Stewart $v$. Many, 7 Brawd. 508.

53 Clark $v$. Dill, II Atl. Rep. (Pa.) 82.

54 Hime v. Klasey, 9 Ill. Ap. r66; Midland R. R. Co. v. Ontario Rolling Mils, to Ont. Ap. 77; Gill v. Benjamin, 64 Wis. 362. 
the doctrine above enunciated in a rather negative form. A few cases, otherwise irreconcilable, can perhaps be solved on the somewhat broader theory of the English Courts, though these decisions can by no means be said to settle the matter. ${ }^{55}$ The question is said to be one of fact for the jury. ${ }^{56}$ This doctrine, which is perhaps only an extension of the familiar doctrine of Ffochster $v$. Delatour ${ }^{57}$ and Frost $v$. Knight, ${ }^{58}$ is an equitable one, though an obviously hard one to apply. The decisions fail to stiggest how one party to the contract will be able to surmise the future intentions of the other party. Moreover, in practice the theory might be dangerous, for no one would be entitled to rescind unless he could persuade the court that his views of his opponent's intentions were correct. Wherever it is adopted the question ought at least to be a question of law for the court and should not be left to the jury. Under these circumstances it may serve to solve contracts which are ambiguous, but it should not be carried further where entirety was intended. It may be added that the rule that failure of one payment will work a forfeiture is the more logical and has the advantage of certainty. In the majority of cases it can work no harm as the instalments are usually equivalent to a fair rent, and the other doctrine savors of a paternal care which the courts ought not to exercise in construing contracts. The vendee should read his contract and failure to do so does not excuse him.59 It may be added that where it is agreed that payments shall be made in notes, and upon default the goods are retaken, the vendor cannot sue upon them. ${ }^{60}$ This is sometimes put on the ground of failure of consideration; but a valid promissory note must be payable unconditionally, ${ }^{61}$ and in another case this is given as the reason why the notes cannot be sued upon. ${ }^{62}$ The vendor should, it seems, return them to the buyer, ${ }^{63}$ and if in the meanwhile he has transferred them, a bona fide purchaser will be entitled to

55 Winchester $v$. Newton. 2 Allen 492, ; Miner v. Bradley, 22 Pick 459;

Stephenson $v$. Cady, II7 Mass. 6.

66 Bloomer v. Bernstein, L. R., 9 C. P. 588.

872 E. \& B. 678 .

68 L. R., 7 Exch. II4.

69 Mallon $v$. Story, 2 Ed. Smith 33r; Harris $v$. Story, 2 Ed. Smith 367;

Ellis $v$. McCormick, I Hilt 313.

60 Minneapolis Harvester Works $v$. Hally, 27 Minn.; Campbell Printing

Press Co. $v$. Henckle, ig Dist. of C. 95.

61 I Pars. Bills \& Notes, 30, 42; Story, Prom. Notes, Sec. 22.

62 rd Natl. Bank v. Armstrong, 25 Minn. 530.

63 Sumer $v$. Woods, 67 Ala. I39. 
collect them out of the property retaken in preference to the seller. ${ }^{64}$

We now come to the more difficult subject of what will entitle the vendee to rescind, upon default in deliveries. It is submitted that much of the conflict in the decisions will be eliminated if we separate the cases in which there was a failure to pay an instalment from those where the failure was in delivery, recognizing that the two sets of cases have little in common. These cases are more difficult of solution because they are seldom made entire by stipulation, and it is often impossible to place the parties in statu quo. If a cross action is the only relief given the vendee will get money instead of the article he wished, and the courts by compelling him to take what he does not want are virtually making a new contract for him. On the other hand, if rescission is allowed cases will arise where the vendee will have taken property without paying for it. It will be necessary to examine a few leading English cases and to trace their influence on American decisions. Before the case of Boone v. Eyre ${ }^{65}$ it is prohable that performance of all the stipulations of a contract on one side was pre-requisite to suit for a breach on the other. But in this case an important and far-reaching change in the law was effected, a view which at first sight seems more equitable being adopted, and it was said that if the covenant broken went only to a part of the consideration and compensation in damages would be an adequate remedy for its breach, then the several covenants could be treated as independent. This is also the doctrine of Pordage $v$. Cole, ${ }^{66}$ though in this case the converse is stated to be true, namely, that if the breach cannot be compensated in damages the stipulation must be construed as a condition precedent, a proposition which does not receive the approval of Mr. Parsons. ${ }^{67}$ The trouble with these cases, and those which adopt the same view is that the doctrine is very hard to apply and leads to an undesirable divergency in decisions of similar facts. The doctrine seems also to beg the question inasmuch as the breach of any contract can be compensated in damages, otherwise the plaintiff would be in equity; but no man wishes to take damages when he has made what he supposes is an entire contract, and on payment of these to be told that he must complete his part. It is debatable, therefore, whether in cases of this sort damages are ever really adequate.

64 Kimball $\nu$. Mellon, 80 Wis. I33.

65 I H. Bl. 273.

66 I Wms. Saund. 3 I9.

67 Pars. on Con., Vol. II. xp. 527. 
Boone v. Eyre, however, has been approved, 68 and doubtless would have remained good law had it not been for the celebrated case of Hoare $v$. Rennie. ${ }^{69}$ This case has probably been as much criticised as any single decision in the English reports and is said to have been decided without previous authority. The contract provided that one hundred and fifty tons of iron should be delivered in four monthly installments. During the first month twenty-one tons only were delivered and it was held that the vendee was thereby discharged. It is impossible to reconcile this case with Simpson $v$. Crippin,70 where it was agreed that from six to eight thousand tons of coal were to be delivered during twelve successive months and the buyer was to supply wagons to receive them. The first month he sent only for one hundred and fifty-eight tons, and yet the seller was held not entitled to rescind. This decision has been criticised as a "strained construction," and it is said to be applicable only to cases where there is a failure to receive the goods, although the principle is really the same.

It remained for Honck $v$. Muller ${ }^{2}$ to cast the weight of authority in England for the doctrine laid down in Hoare $v$. Rennie. In this case failure to accept any of the first instalment of goods was held to discharge the seller. Simpson $v$. Crippin was thus practically overruled though it was distinguished on the ground that the contract had been in part performed and therefore could not be rescinded, it being an elementary principle that the right of rescission cannot be had when the parties cannot be placed in statu quo. ${ }^{73}$ This does not seem a very logical explanation, however, and Hoare $\%$. Rennie has been since approved and may be said to be the law of England, ${ }^{74}$ with some modifications which will be noticed later. In America there has been much conflict in the decisions. It is decided by respectable authority that when it is agreed that goods are to be delivered at a specified time the vendee is not bound to take them at a subsequent time, ${ }^{\text {ro }}$ but this is very far from saying that it

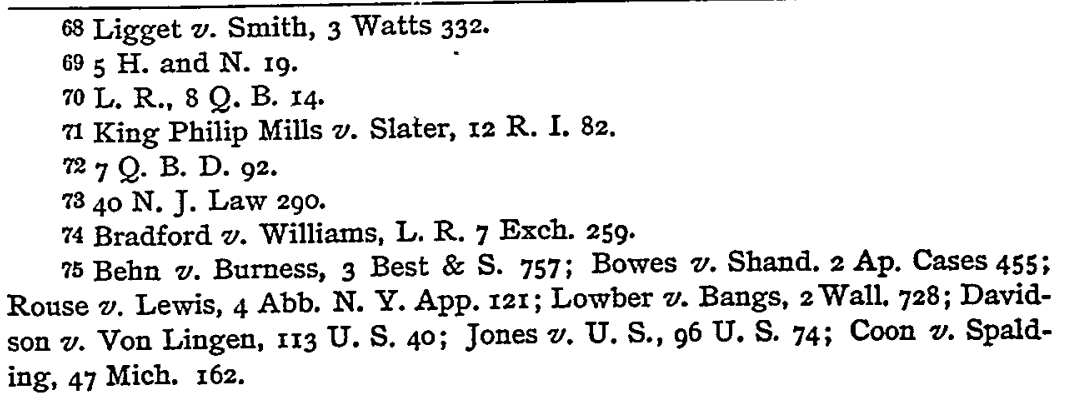


relieves the purchaser from all the subsequent obligations of the contract.

In Pennsylvania the court holds to the doctrine of Simpson $v$. Crippin, not forgiving the default because it wishes to excuse it, but because in its view to hold these contracts entire is not a proper construction, and therefore the most practicable remedy is by cross action. ${ }^{76}$ Mississippi also considers that it is no ground for rescission that a party does not comply with some of the stipulations in a contract if there are other provisions independent of those in which default has been made.77 Again it is said that such contracts will not be held entire unless the stipulations broken are "made to depend upon the performance of the whole of the covenants in the entire contract." 78 New Jersey holds that these contracts are severable, ${ }^{79}$ but the court in this State has gone a little further and has applied the rule heretofore mentioned in regard to failure to make payments, namely, that the vendee would be entitled to rescind if the circumstances of non-delivery were such as to induce a reasonable belief that the vendor did not intend to carry out his contract, ${ }^{80}$ and this seems also to be the view taken in New Hampshire. ${ }^{81}$ This was held in spite of the fact that Lord Chancellor Selborne expressly says, in Mersey Steel Co. $v$. Naylor, that the rule only applies to the case of a buyer failing to pay. So, also, perhaps, the vendor would be excused from going on with the contract if circumstances render it impossible for the vendee to carry out the contract, as in the case of insolvency, although this has been disputed. ${ }^{22}$ This is an uncertain term and the distinctions are finely drawn. The mere fact that the vendee has not money enough in hand to meet his obligations in the ordinary course of business will not in itself constitute insolvency; ${ }^{83}$ he must be unable to pay his debts. ${ }^{84}$ But insolvency once established, this in itself only relieves the vendor from giving credit, and if the vendee is able to pay the instalments due, would not excuse the vendor. 85 It is probable, how.

76 Obermeyer v. Nichols, 6 Binn. 159; Morgan v. McKee, 27 P. F. Smith 228.

77 Dunlap v. Petrie, 35 Miss. 590.

78 Hewitt v. Berryman, 5 Dana (Ky.) r65.

79 Gerli $v$. Poidebard Silk Mfg. Co., 3r Atl. Rep. 40r.

80 Blackburn $v$. Reilly, 47 N. J. Law 29o.

81 Hamer $v$. Tucker, 50 N. H.

82 N. E. Iron Co. v. Gilbert R. Co., 9r N. Y. I53.

83 Smith $v$. Collins, 94 Ale. 394.

84 Cunningham $v$. Martin, I25 U. S. 77.

85 Pardee v. Kanaday, roo N. Y. I2I. 
ever, that the vendee must pay for future deliveries also to entitle him to a completion of the contract. ${ }^{86}$ But the fact that the vendee has given his note will not prevent the vendor from rescinding. ${ }^{87}$ And in many States it is held that in case of rescission the vendee must return the articles delivered, or their value. 88 For a long time the weight of authority in America seemed to be in favor of Simpson $v$. Crippin, and this was the view taken by Mr. Benjamin in his work on "Sales." 59 But in Mr. Corbin's edition of this work the contrary is stated. The reason for this opinion is possibly the case of Norrington $v$. Wright, ${ }^{90}$ which not only decided that time was of the essence of these contracts, which, as before mentioned, may be regarded as settled by a long line of decisions, but also, in an emphatic opinion, held that failure to deliver the first instalment was a competent ground for rescission. The reasoning of Hoare $v$. Rennie was expressly adopted by the court. While an important decision, it can hardly be said to have exercised much influence in those States which before leaned toward the opposite theory. In New York, however, the doctrine of Norrington $v$. Wright is expressly adopted, ${ }^{91}$ and the principle of entirety as early laid down in Champion $v$. Rowley, ${ }^{92}$ disapproving the old English case of Oxendale $v$. Wethere11, ${ }^{93}$ may be said to be settled law. This later Court of Appeals' decision practically overrules some earlier cases in the lower courts, which seem to lean the other way, ${ }^{94}$ and still another case, it is submitted, may be distinguished on the ground that the right of rescission was unwarrantably delayed.95 'This was the law of New York, however, before the case of Norrington $v$. Wright, the case of Catlin v. Tobias ${ }^{96}$ being a leading authority on the subject. In this case the vendor agreed to deliver a certain number of bottles in instalments for use in the vendee's business, and upon default in

86 Ex parte Chalmers, L. R., 8 Ch. 289.

87 Diem $v$. Kobletz, 49 Ohio St. 4r.

88 Gage $v$. Mayers, 59 Mich. 300; Polhemus $v$. Holman, 45 Cal. $573 ; 6$

Houston 42I; 36 Mo. App. 567; 59 Wis. 272; 43 Iowa, 339.

89 Benj. on Sales, Sec. 909.

90 II5 U. S. I88.

91 Pope $v$. Porter, 102 N. Y. 366.

92 r8 Wend. 185.

93 g B. \& C. 386.

94 Snook $v$. Fries, 19 Barb. 313; Lee $v$. Beebe, I3 Hun. 89; Talmage $v$.

White, 3 J. \& S. 218; Swift $ข$. Opdyke, 43 Barb. 274. Contra: Visscher $v$.

Greenbank, II Hun. I59.

95 Cahen $v$. Platt, 69 N. Y. 349.

9026 N. Y. 
delivery it was held that the vendor could not recover for the bottles already delivered. The Court held that under the contract the vendee had the right to use the bottles without waiting to see whether the vendor would complete his contract, and therefore need not return them. The court went further, and held that the same principles would apply even if each month's delivery were regarded as a separate contract. And in a later case it was said that conceding that the contract was severable the vendor must at least make one delivery according to its terms. ${ }^{97}$

Maryland also adopts the view of the New York courts, provided, however, that the vendee give reasonable notice to the vendor of his intention to rescind; 98 and so does Rhode Island; 99 while in Kentucky it was held that performance on one side was a condition precedent unless some benefit was received on one side which it would be inequitable to allow that side to retain. 100 It will be seen, therefore, that it can scarcely be said that the weight of authority is in either direction, but the States take widely diverging views upon the subject. It may be remarked, nevertheless, that the most carefully considered decisions apply the doctrine of entirety as the safer rule in a greater number of cases. Bramwell, L. J., in Honck v. Muller, suggests the case of a sale of a suit of clothes, and asks whether, if a coat and vest should be delivered and there should be a default in the delivery of the trousers, the vendee could be compelled to pay for the coat and vest. This is an excellent test of the fairness of the rule. In some States the unfortunate buyer would have to pay for the portion of the suit he had received and spend time looking for a pair of trousers to match; in others, he would be compelled only to return the coat and vest, but supposing it to have become moth-eaten or otherwise spoiled, it would be an open question as to whether he must pay their value; while in the United States courts, New York and a few other States, he could wear the coat and vest without paying a cent for it. It will be seen that none of these rules give an exactly fair result. The chief difficulty which has been suggested in following Norrington $v$. Wright was pointed out by Bramwell, L. J., in Honck $v$. Muller, notwithstanding he was one of the majority of the court in approving Hoare $v$. Rennie. Subsequently he repudiated this

97 Nightingale v. Eiseman, I2I N. Y. 288.

98 Bollman $v$. Burt, 6r Md. 4I5.

99 King Phillip Mills v. Slater, supra.

100 Trimble $v$. Green, 3 Dana 357. 
dictum in Mersey Steel Co. v. Naylor, but the difficulty remains. 'This occurs where the failure is not in the first delivery but in a second or subsequent delivery. As was said by the New Jersey Court, ${ }^{101}$ the delivery of the first instalment does not on principle seem to stand on any different footing from the delivery of any subsequent instalment; and yet if we apply the doctrine of Hoare $v$. Rennie to a second instalment we are running counter to the well-known principle that the right of rescission must not be exercised unless we can restore the parties to their original position.

Most of the cases cited which allow a breach upon a failure to deliver the first instalment can be easily reduced to conformity with the rule already mentioned as in force in New Jersey, that rescission will be allowed only where the default evinces an intention not to carry out the contract. It will be seen that the failure to deliver the first instalment is much more likely to be given this construction than a subsequent default, which would more probably be the result of accident. But it is submitted that any rule of law which compels the vendee, if the default is on a second or subsequent instalment, to return the goods received or their value cannot arise from a true construction of these contracts, but from a desire not to impose a forfeiture on the vendor. Such a rule practically says to the vendee, "The vendor has not carried out his part of the contract, but in the interest of fairness we will say that what he has done practically constitutes a contract between you. Although the goods you have received may be of no use to you, although they are not what you contracted for, still you must pay for them, being content to recoup damages for your vendor's failure," thus making a breach of contract in itself a new contract between the parties. The vendee would lose much of the advantage which might be gained by successive deliveries, because he could never be sure they would ever be completed. If he wanted a less quantity he could contract for that amount in the first place in one delivery, making his own contract and not letting the court make one for him; if, on the other hand, he wanted a larger quantity it would seem that to be safe he must order it all at once to be delivered in one instalment. Contracts are made to be kept and not broken, and the courts should be only too willing to adopt a rule which will be an incentive to keep them. Any other rule will permit the vendor to keep a contract if favorable to him or break it if it prove disadvantageous. Such a "con-

101 3r Atl. Rep. 40r. 
struction" of these contracts as the above is not logical, and it can have no force in a State like New York, where the doctrine of entirety has a firm hold. In this State at least the case of Catlin $v$. Tobias seems to be authority for the view that failure to deliver a second instalment would work a forfeiture equally with a default in the first delivery, and this view is taken by a case in a lower court. ${ }^{102}$

In view of the conflicting decisions and the unfairness of either rule in given cases, a rule is with diffidence suggested for which the writer can cite no authority. Where the contract is for the sale of goods of the like of which there is no dearth on the market upon default in a delivery the vendee should be allowed to make a new contract with another vendor for delivery of the remainder. He should pay the first vendor for what he had delivered, and should be allowed to counterclaim damages for failure to deliver the remainder the measure of which would he the difference in the price of the goods under the new agreement and the old. In cases of this sort such a rule can do no harm. But where the contract is for the delivery of rare and valuable articles, or goods of a particular manufacture or brand, the forfeiture should be enforced, on the principle that "where there has been no beneficial service there shall be no pay." 103 It may very well be that the vendee would have but little use for a lesser quantity of such articles as these and he perhaps could not obtain the remainder of a quality to suit him elsewhere. Certainly, if the rule of Harmony $v$. Bingham ${ }^{104}$ is good law, that a vendor is not excused by act of God, he should not be excused under an entire contract where the failure to deliver was due to his own fault.

Where the vendee sues for failure to deliver the vendor may show in reduction of damages that the vendee could have obtained the same goods from others at the same price. ${ }^{105}$ This would seem to be in accordance with the first part of the above rule. Or he may show unreasonable delay in exercising the right to rescind. 106 Or he may show a waiver, as the acceptance of a smaller amount, ${ }^{107}$ but a waiver of one delivery does not give the buyer the right to carry this waiver over "to the next

102 Levene $v$. Rabbitte, 2 N. Y. Supp. 389.

103 Farnsworth v. Garrard, I Camp. 38.

104 I Duer. 209.

105 Saxe v. Penokee Lumber Co., Ir Ap. Div. 29I.

106 Morgan v. McKee, 77 Pa. 228; Byers v. Chapin, 28 Ohio 300.

107 Avery $v$. Wilson, 8I N. Y. 34I; Silberman v. Fretz, I2 Ap. Div. 328. 
instalment and demand the amount then due together with the deficiency of the preceding instalment." 108 Or he may show that the vendee has prevented performance. ${ }^{109}$ Parol evidence may be admitted to show that a written contract of sale has been enlarged and more deliveries provided for. ${ }^{110}$ The failure to deliver does not work a forfeiture unless the buyer choose to regard it as terminated, 111 but if he choose to rescind he must do so in toto, 112 and unequivocally. 113 When the contract has been rescinded, in those States where the vendor is allowed to recover for what he has already delivered his remedy would be on a quantum meruit. 114 If the subject of the sale were animals and, without the knowledge of either party, they were dead at the time of contract, or if merchandise were destroyed by fire under similar circumstances, the sale would be thereby avoided; 115 though if part only were destroyed the buyer would have his option to taike the remainder with an abatement of the price. 116 Where nothing was agreed upon as to the time of delivery of the various instalments the question would be one for the court, ${ }^{117}$ whether the delivery was made within a reasonable time. ${ }^{118}$ If the goods are to be delivered, "as fast as they may be produced," they should be delivered as fast as the operation of the vendor's plant will permit. 119

It is now proposed to inquire briefly as to where the title to the goods remains in sales by instalments. This is largely a matter of public policy in each State, and the question is one of importance for it is a recognized principle of the law of personal property that no man can be divested of it without his consent. 120 And as is said in Shepherd's "Touchstone": 121 "It is a general rule that when a man hath a thing he may condition with it as

108 Johnson $v$. Allen, 78 Ala. 387.

109 Rouse v. Lewis, 4 Abb. N. Y. App. I2I; Young v. Hunter, 6 N. Y. 203; Holmes $v$. Holmes, 9 N. Y. 525.

110 Ham $v$. Cerniglia, 73 Miss. 290.

111 O'Neill $v$. James, 43 N. Y. 84 .

112 Raymond $v$. Barnard, 22 Johnson 274; Hogan $v$. Weyer, 5 Hill 39o;

Moyer $v$. Shoemaker, 5 Barb. 322.

113 Hunt $v$. Siger, I Daly 209; Ehrensperger v. Anderson, 3 Exch. I58.

114 Planche $v$. Colburn, 8 Bing. 14 .

115 Wood \& Foster's case, I Leon. 42.

1102 Kent Com. 469.

1172 Greenl. 249.

118 Sawyer $v$. Hammott, I5 Me. 40.

118 Stewart 2 . Marvel, ro1 N. Y. 357 .

12020 Wend. 275 ; I Hill 303 .

121 Shepherd's Touchstone, Ir8, IIg, I20. 
he will. A contract or sale of a chattel personal, as an ox or the like, may be upon condition and the condition doth always attend and wait upon the estate or thing whereunto it is annexed; so that although the same do pass through the hands of an hundred men, yet it is subject to the condition still." This is still substantially the law in Massachusetts and the title to the property remains in the vendor until all the payments are made, and he can follow the property even in the hands of an innocent purchaser. ${ }^{122}$ He may retake the goods from his vendee or sub-vendee without notice, ${ }^{123}$ or even from an attaching creditor of the vendee. ${ }^{124}$ To entitle him to do this the parties must have intended that the title remain in the vendor, ${ }^{125}$ and delivery without requiring payment is presumptive evidence of a contrary intention, ${ }^{126}$ the burden of proof being on the vendor to show the true intention of the parties. ${ }^{127}$ When this intention is evident the vendee gets no title whatever until payments are made, and consequently can given none. ${ }^{128}$ The vendor could, therefore, on condition broken, give good title to some new purchaser without actually retaking possession of his property. ${ }^{129}$ Nor would a policy of insurance be discharged by such a contract of sale. 130 But before the day mentioned for payment the vendor, it seems, cannot bring trover for the goods.131 Upon payment the vendee acquires title to the property without further bill of sale, ${ }^{132}$ and in Rhode Island it is said that the vendee has such possession that he may sell or mortgage the goods and that upon payment of the last instalment the title of the mortgagee or sub-vendee would defeat an attachment for debt by the original vendor. ${ }^{133}$ This same general rule is applied in some other States, ${ }^{134}$ but in New Jersey the vendor must not

122 Merrill $v$. Bank of Norfolk, Ig Pick. 32.

123 I26 Mass. 482; 103 Mass, 5I7; 9 Allen 77 r.

$124{ }_{3}$ Cush. 257.

125 Denney $v$. Williams, 5 Allen 3.

126 I Seld. $45 ; 6$ Pick. 266.

127 Riddle $v$. Varnum, 20 Pick. 283.

128 Cogill $v$. Hartford \& N. H. R. R., 3 Gray 545 ; Deshon $v$. Bigelow, 8 Gray I59; Barrett $v$. Pritchard, 2 Pick. 512; Reed $v$. Upton, ro Pick. 522.

129 Hubbard $v$. Bliss, I2 Allen, 590.

130 Boston \& Salem Ice Co. v. Royal Ins. Co., I2 Allen 38I.

131 Newhall $v$. Kingsbury, I3r Mass. 445.

132 Currier $\nu$. Knapp, II 7 Mass. 324; Chase $v$. Ingalls, I22 Mass. $38 \mathrm{r}$.

133 Carpenter $v$. Scott, I3 R. I. 477.

131 Sanders $v$. Keber \& Miller, 28 Ohio St. 630; Cole v. Berry, 42 N. J. Law 308; Tibbetts $v$. Towle, 12 Me. 34I; +1 Cal. 455; I Wis. 14I; 16 Mich. I58; 38 Tex. 234; Bradshaw v. Warner, 24 Ind. 58. 
give the vendee any indicia of ownership beyond mere possession or be guilty of conduct which the law would consider fraudulent. ${ }^{135}$ This seems to be the law in England, ${ }^{136}$ and doubtless the latter part of the rule would hold good everywhere. It is on the ground of constructive fraud that other jurisdictions have refused to allow the title to remain in the seller as against creditors or bona fide purchasers from the vendee, ${ }^{137}$ and Pennsylvania stands very strongly by this rule. In Illinois they admit that mere possession of goods will not defeat title in the true owner, ${ }^{188}$ and that the presumption of title arising from possession of personal property may be overcome, ${ }^{139}$ but they refuse to apply this principle to conditional sales and it is well settled that as against creditors or bona fide purchasers reservation of title in the original vendor is invalid, 140 and with this view other States agree. ${ }^{141}$ In New York a rather untenable and useless distinction is taken between conditional sales and conditional deliveries. ${ }^{142}$ In the early case of Wait $v$. Green, ${ }^{143}$ it was thought that it would not be public policy to allow the vendor to reserve title against an innocent purchaser. This case was supported by a large number of early decisions. ${ }^{144}$ The case was "distinguished" by Ballard v. Burgett, ${ }^{145}$ and was for all practical purposes overruled, and as this case has been subsequently approved, ${ }^{146}$ there is no doubt that in this State the original vendor could retain good title. It is submitted that there is no real distinction between conditional sales and conditional deliveries, but that it arose from the not very praiseworthy desire of the Court of Appeals not to overrule Wait $v$. Green. At any rate the distinction is one which other courts have been unable

195 Marvin Safe Co. v. Norton, 48 N. J. Law 4ro.

136 Dyer $v$. Pearson, ro Eng. C. L. 20.

137 Heryfard $v$. Davis, ro2 U. S. 235; Hervey $v$. R. I. Locomotive Works, 93 U. S. 664; Copeland v. Bosquet, 4 Wash. Cir. C. R. 594; Rose v. Story, I Pa. St. I9o; Haak v. Linderman, 64 Pa. St. 499; Martin v. Mathiot, I4 S. \& R. $2 r_{4}$.

138 Klein v. Siebold, 89 Ill. 540.

139 Fawcett $v$. Osborn, 32 Ill. 4 II.

140 Murch $v$. Wright, 46 Ill. 487; Jennings v. Gage, I3 Ill. 6ro; Brundage ข. Camp, 21 Ill. 330; McCormick $v$. Hadden, 37 Ill. 370.

141 Vaughn $v$. Ricketts, I874 Ky. Ct. of Appeals; Gerrish v. Clark, $64 \mathrm{~N}$. H. 492.

142 Comer v. Cunningham, 77 N. Y. $39 \mathrm{I}$; Dows $v$. Kidder, 84 N. Y. I2I. $14836 \mathrm{~N} \mathrm{Y}$.

144 Smith $v$. Lyons, 5 N. Y. 4I; 25 Barb. 474.

14540 N. Y.

140 Austin $\%$. Dye, 46 N. Y. 
to see. It is suggested that the New York rule is the same as the Massachusetts rule, though probably the courts would be more ready to find grounds of estoppel on the part of the original vendor, for it is stated that "where the owner of property confers upon another an apparent title to or power of disposition over it he is estopped from asserting his title as against an innocent third party who has dealt with the apparent owner in reference thereto without knowledge of the claim of the true owner."147 It is probable, also, that the courts here would be ready to apply the rule laid down in California, that if it may be seen from the entire transaction that the title is to pass, and that the form of sale was only adopted in order to give greater security to the vendor the reservation will be void.148 It may be added that when the purpose of the sale is that the vendee place the goods again on sale the reservation of title in the original vendor will be void against purchasers. ${ }^{149}$ Although in New York it seems that such sales are not void against creditors, they may levy upon the goods in the hands of the vendee, and pay to the vendor the purchase price thereof, and thereby acquire title themselves, ${ }^{150}$ though this could not be done after the time for payment had expired. ${ }^{151}$ The Massachusetts rule seems to the writer the more logical (and in point of fact the New York rule is practically the same) than the Pennsylvania or Illinois rules. There seems to be no good reason why the rule of caveat emptor should not apply in these cases, and certainly following too strictly the doctrine of Twyne's Case on which the other rule is based is bound to work injustice in the end. Moreover, there is no justice in making the original vendor give credit when he does not choose to do so. If credit be given the sale passes title, ${ }^{152}$ and if the vendor take other security the title to the goods will not remain in him, but the taking of a note is not such security as will pass the title. ${ }^{153}$ There does not seem to be much hardship therefore in the case of an innocent purchaser finding that the title was reserved in the vendor and while, as was pointed out by the Connecticut Court, "it is the established policy of our law to hold a man's property subject to

147 McNeil v. Tenth National Bank, 46 N. Y. 325.

148 Palmer v. Howard, 72 Cal. 293.

$149 \mathrm{Mfg}$. Co. v. Carmen, 9 N. E. Rep. 707; Cole v. Mann, 62 N. Y. I.

150 Frank $v$. Batten, 49 Hun. 9r.

151 Buckmaster and Smith, 22 Vt. 203.

162 Leonard $v$. Davis, I Black. 476.

163 Campbell Printing Press Co. v. Walker, II4 N. Y. 7. 
the payment of debts, yet $* * *$ a man may appear to have, and in fact, actually have, a valuable interest in property which is beyond the reach of legal process. *** Should evils spring up under the law as it now is, the Legislature, it is to be presumed, will in due time provide the proper remedy." 154 The statute which is intended to provide for this in New York 155 is a flagrant example of the corrupt and slipshod legislation of this State. Everything is excepted from the statute whose manufacturers desired to continue sales on the instalment plan, and almost every year some new list of articles is excepted, so that now it has almost no application to the law of instalment sales. It may be remarked, also, that the statute does not affect the rights of creditors and protects only subsequent purchasers and mortgagees without notice, ${ }^{156}$ and that the remedy required, as pointed out by the Connecticut Court, is wanting. The statute is construed strictly; it would seem that it must be strictly complied with, and in those States where the statute applies to creditors it would protect creditors before the sale as well as after, and even if they had knowledge of its terms. ${ }^{167}$ It is well settled that property placed upon realty under a contract that title shall not pass to the vendee will not become a part of the realty. ${ }^{158}$ And if goods are to be placed in a deliverable state and payment made as the work progresses the title will not pass. ${ }^{159}$

It is said that the lex loci of these contracts should govern, ${ }^{160}$ but in New Jersey a Pennsylvania vendor was allowed to reclaim his property in New Jersey, though in his own State he would not have been allowed to do so. ${ }^{161}$ This shows that in this class of sales public policy, with its consequent uncertainty, is more apt to govern than settled rules of law.

Raymond Sandford White.

154 Hughes $v$. Kelly, 40 Conn. I48.

155 Laws of 1884, Ch. 315; Laws of 1895, Ch. 925 ; Laws of 1896. Ch. 6or. 156 Frank $v$. Batten, 49 Hun. 9r.

157 Collins v. Wilhoit, I08 Mo. 451. Contra : Morton v. Tuck, 82 Ga. 230.

16856 Miss. 552.

159 Andrews 2 . Durant, II N. Y. 35.

160 Dixon $v$. Blondin, 58 Vt. $689 ; 2$ Brawd. I29.

16148 N. J. Law 410. 